Article

\title{
The Existence of Multiple Hydro-Mentalities and their Implications for Water Governance: A Case Study from Sri Lanka
}

\author{
Kavindra Paranage *(D) and Nancy Yang \\ School of Social Sciences, Monash University, Wellington Road, Clayton, VIC 3168, Australia; \\ nancy.yang@monash.edu \\ * Correspondence: kavindra.paranage@monash.edu
}

Received: 16 June 2020; Accepted: 16 July 2020; Published: 18 July 2020

\begin{abstract}
Traditionally, the literature on water management has considered water from a techno-realist point of view by focusing on finding the most effective technical solutions to distribute the largest quantities of water among populations. This paper takes an alternative position by suggesting that particular "ways" of managing water are culturally embedded and that water management practices stem from an underlying hydro-mentality among water users and system designers. To this end, we explore two different water systems in Sri Lanka and argue that each system is underpinned by a particular hydro-mentality that influences the ways in which water is managed by downstream communities.
\end{abstract}

Keywords: hydro-mentality; irrigation; Sri Lanka; water; water management

\section{Introduction}

Recently, attention has been brought to the idea of a "multiplicity of worlds animated in different ways" [1]. This supposition has challenged the assumption of an objective reality that is "out there", fixed and potentially manageable by humans according to established knowledge hierarchies. Further, this line of thinking in scholarly work has brought to the forefront the fact that there may be diverse ways of being within and interacting with multiple worlds. In a set of recent contributions, for example, Blaser [1-3] has drawn attention to the limitations of environmental policies that dismiss ontological dimensions as cultural constructions. Drawing on a case study based on the Yshiro people of Paraguay, Blaser [2] illuminates how a failure to take into consideration the traditional ontologies of the Yshiro people regarding animals (i.e., the ways in which the Yshiro people have conceptualized animal-human relationships) has resulted in a wholesale breakdown of wildlife conservation efforts. The present paper seeks to expand this multiple-ontological approach to the study of natural resources and specifically to the use, management, and governance of water. It does so by focusing on a case study undertaken in Sri Lanka that examines a philosophy of water management that guides irrigation based water use in Sri Lanka.

Traditionally, the literature on water management has considered water from a techno-realist point of view by focusing on the use and management of water resources as a zero-sum phenomenon (except research on "hydro-hegemony" that analytically frames transboundary water conflicts [4-6] in terms of underlying power asymmetries). In other words, the literature on water use and management has focused on finding the most effective technical solutions necessary to distribute the largest quantities of water among populations. This literature has spawned a number of perspectives: the colonial water infrastructural mindset that promotes state-sponsored technical structures for water management (dams, canals, etc.), the neo-liberal hydro-mentality that first brought private-sector funding to the arena 
of water management, and the concept of integrated water resource management (IWRM) that seeks to harmonize water management techniques with broader principles of sustainable development $[7,8]$. While the development of the key concepts and techniques mentioned above has arguably contributed a variety of useful tools to the water manager's arsenal, it can alternatively be argued that focusing attention on the best ways of managing water largely fails to take into account potentially different philosophies of water management held by different social and cultural groups-and this latter concern best sums up the focus of the present work. Put differently, this work does not seek to realize which water management practice operates best in terms of serving the needs of a population (which is the focus in the mainstream literature on water management). Rather, it examines how different social and cultural groups construct diverse philosophies of water that heavily influence their unique water management patterns and styles. In essence, the work seeks to discuss the possibility of multiple hydro-mentalities that exist in regard to water and how these different hydro-mentalities have a very real effect in shaping water management practices across various socio-cultural groups.

By exploring the implications of the socio-cultural construction of water and the notion of hydro-mentalities within Sri Lankan irrigation systems, the present work also contributes most directly to a growing body of literature on hydrosocial territories that is reformulating our understanding of the nature of water and human-water relations [9-15]. This new and growing research agenda focuses on how water shapes our social worlds through multiple material engagements and assemblages [16] and notes how water and water-related infrastructure is often a space that is contested, with different assemblages of actors, discourses and interests seeking to establish particular forms of infrastructure to control water flows in certain ways to achieve predetermined ends.

However, there is still a relative dearth of studies that expand on how socio-cultural views and perceptions related to water held by communities has a hand in shaping water infrastructure (i.e., subjective "hydro-mentalities"). The work of Boelens et al. [17] in particular communicates the central concern of this paper-that there are multiple socio-cultural aspects that influence the views of water and water management and that there is a clear political dimension related to selecting which hydro-mentalities hegemonically prevail over others.

\section{A Perspective from Sri Lanka}

Sri Lanka, officially the Democratic Socialist Republic of Sri Lanka, is an island country in South Asia located in the Indian Ocean southwest of the Bay of Bengal and southeast of the Arabian Sea. It is separated from the Indian subcontinent by the Gulf of Mannar and the Palk Strait [18]. Sri Lanka has an extensive history of managing water for irrigation purposes and employs several alternating systems of water management, therefore rendering it a likely candidate to benefit from a multiple hydro-mentalities analysis. Among the different water management systems currently in use in Sri Lanka, this paper focuses on two particular systems of irrigation based water management: the tank cascade system and the surface irrigation system. The tank cascade system has been used to manage water at the village-level through rain-fed irrigation while the surface irrigation system has been utilized only since the latter half of the 20th century to manage water across large-scale irrigation fields promoting commercialized agriculture $[19,20]$. The two models differ considerably in terms of their practices of water use, management, and governance [21], but are often found in very close proximity to each other. The argument that shall be sustained through the present work is that different implementation decisions made regarding water management within these two models reflect deeper differences between the underlying philosophies regarding water. In sum, each system of water management is underpinned by unique hydro-mentalities socially constructed through an assemblage of social institutions.

\section{Materials and Methods}

The present work examines two irrigation based water managements systems used in Sri Lanka: the tank cascade system and the surface irrigation system. Historical records on irrigation indicate that 
the tank cascade system has existed in Sri Lanka for approximately a millennium [22]. Recently, the tank cascade system design has been listed as a United Nations heritage site [23]. On the other hand, the surface irrigation system design of water management has been a relatively recent development introduced as part of large-scale agriculture extension programmes pervading Sri Lanka since the 1950s [24]. More specifically, the introduction of the surface irrigation system for agriculture extension and water management has been a major feature of the Mahaweli Development Project, the cornerstone of modern Sri Lanka's efforts to commercialize agriculture [25-27]. Both irrigation systems co-exist in the North Central Province of Sri Lanka (see Figure 1), which is where the fieldwork for the present study was carried out.

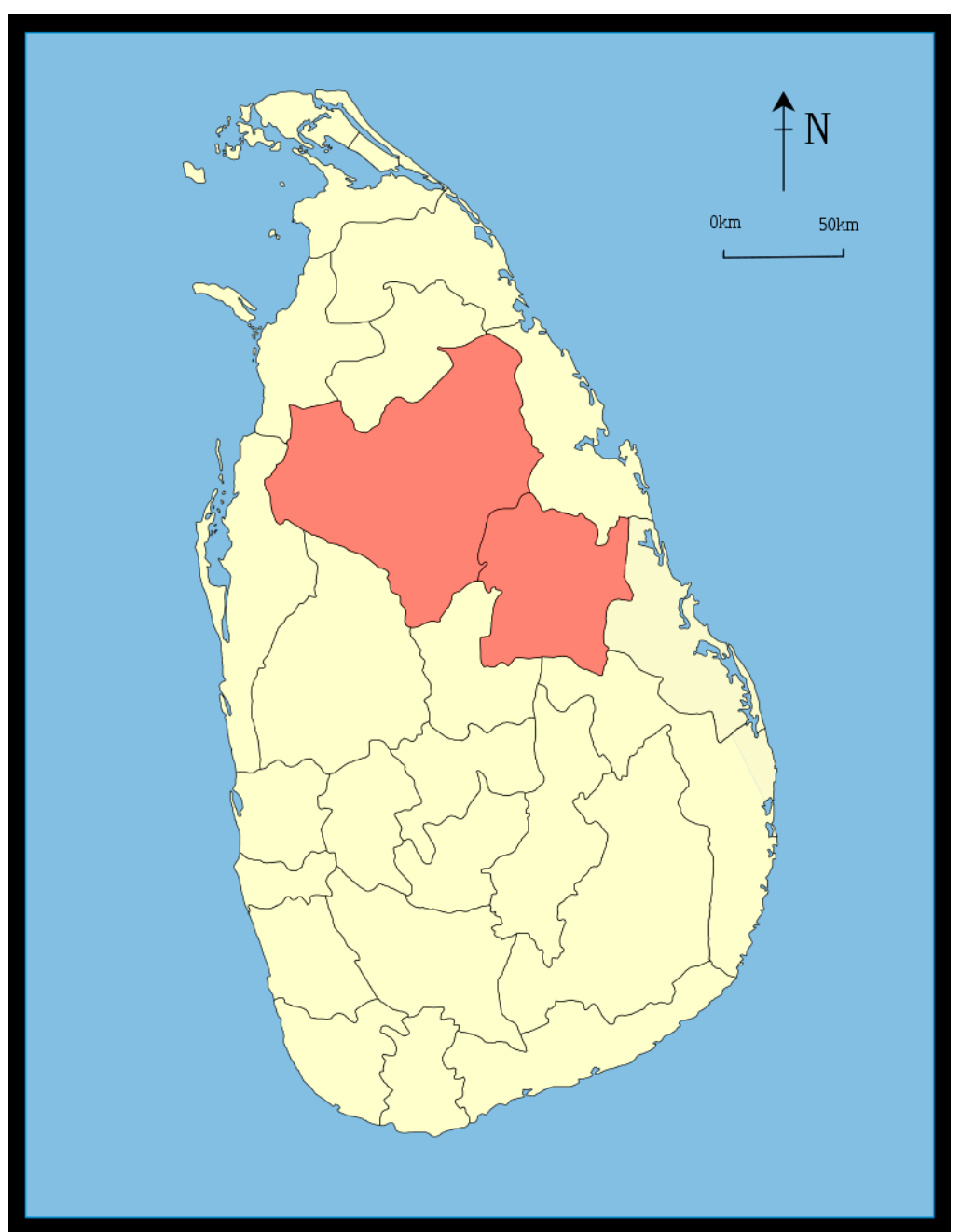

Figure 1. The North Central Province of Sri Lanka (highlighted in red) Reproduced with permission from [The Planning and Monitoring Unit of the Mahaweli Authority of Sri Lanka]; [2018].

The tank cascade system investigated over the course of this study is located in the village of Palugaswewa, while the surface irrigation system (which also forms part of the Mahaweli Development Project; see above) examined is located in the village of Thambuttegama. In each village, the data collection involved employing a qualitative methodology based on field observations (recorded in a field diary), a combination of semi-structured and unstructured interviews with farmers ( $\mathrm{N}=23$ farmers of the Palugaswewa tank cascade system and $\mathrm{N}=25$ farmers of the Thambuttegama surface irrigation system), and focus group discussions ( $\mathrm{N}=2$ farmers of the Palugaswewa tank cascade system and $\mathrm{N}=3$ farmers of the Thambuttegama surface irrigation system). Our use of this qualitative and exploratory research design is justified on the basis that understanding how different philosophies 
and ideologies among different socio-cultural groups gives rise to unique hydro-mentalities requires an articulation of the perspectives of the participants studied [28]. This collection of primary data was supplemented with detailed maps of the water infrastructure of the tank cascade and surface irrigation systems, detailed plans and documents that have guided the planners of various irrigation system designs (including the Master Plan for the Mahaweli Development Project and its documented budget), documents (archived records) describing the land use patterns, the land tenure systems in place, and a comprehensive layout of the cultivated land plots.

Another notable feature that will inform our discussion later is the fact that farmers of the Thambuttegama surface irrigation system were (formerly) also cultivators in the tank cascade system. This is because-prior to the development of surface irrigation systems by the Mahaweli Development Project - the North Central Province was home to an extensive network of small and moderate-sized tanks that were linked in a cascade model. The Mahaweli Development Project terraformed major portions of the North Central Province when creating the new surface irrigation system, with earlier tanks being eliminated wholesale. After the development of the new infrastructure necessary to sustain the surface irrigation systems, the government of Sri Lanka colonized the new system with farmers who were displaced in the elimination of the old cascade system. Thus, a subset $(\mathrm{N}=12)$ of the farmers interviewed from the Thambuttegama surface irrigation system were also previous incumbents of the older tank cascade system. As such, this subset of interviewees occupies an important vantage point that enables us to contrast the different hydro-mentalities existing in each system.

Finally, the farmers interviewed from the Palugaswewa tank cascade system broadly agreed with one another in relation to how they perceived and engaged with their respective water systems. They were also in agreement that the tank cascade system was superior to modern irrigation practices in terms of the former's eco-friendly philosophy towards water and its management. On the other hand, the farmers interviewed from the Thambuttegama surface irrigation system, while agreeing on how they perceived and engaged with their water system, disagreed as to the advantages and disadvantages associated with it. Particularly, the subset of the farmers interviewed from the Thambuttegama surface irrigation system who previously cultivated in the tank cascade system were sharply divided in their approval of the new irrigation practices. While we explore the drivers and connotations of this disagreement in relation to our focus on hydro-mentalities, we do not undertake a scientific or heuristic evaluation of the relative strengths and weaknesses of each system, as it will be beyond the scope of this paper.

\section{Results}

This section documents the different hydro-mentalities-operationalized as a socio-cultural construction of what water is and how it should be governed-that characterize the two different irrigation based water management systems discussed in this work. It also examines how these hydro-mentalities translate into actual water management decisions and policy-based interventions, calling attention to the fact that differences in hydro-mentalities have real consequences for water use, management, and governance.

\subsection{The Hydro-Mentality Characterizing the Tank Cascade System}

The tank cascade system of water management was first proposed by Bandara [29] to describe a network of small tanks for large reservoirs that still exist in modern day Sri Lanka. These ancient irrigation structures have evolved with the advancement of traditional knowledge over two millennia and still act as essential elements of water management for agriculture in the dry zone of Sri Lanka. The main principle behind tank cascade systems lies in the recycling and re-use of water through a network of small to large tanks. Brohier [30] has also reported on village tanks and on their associations with ancient irrigation works in Sri Lanka. A "cascade" is a connected series of tanks organized within a micro- (or meso-) catchment of a dry zone landscape for storing, conveying and utilizing water from an ephemeral rivulet $[21,29,31]$. Each of these cascades delineates a distinct small watershed or 
meso-catchment ranging from 13 to $26 \mathrm{~km}^{2}$ with an average size of $20 \mathrm{~km}^{2}$. The tank cascade system is composed of a tank (a sub system) that forms an interwoven irrigation network. Tanks, paddy fields, watersheds and canals are integrated and interwoven within the natural environment (naturalized), which has facilitated the evolution of the cascade system for over a millennium [31,32]. The tank cascade system of water management uses rainwater and small streams as water sources. Water is stored in small tanks and is used to cultivate downstream areas; once used, the water trickles down to progressively larger tanks (See Figure 2).

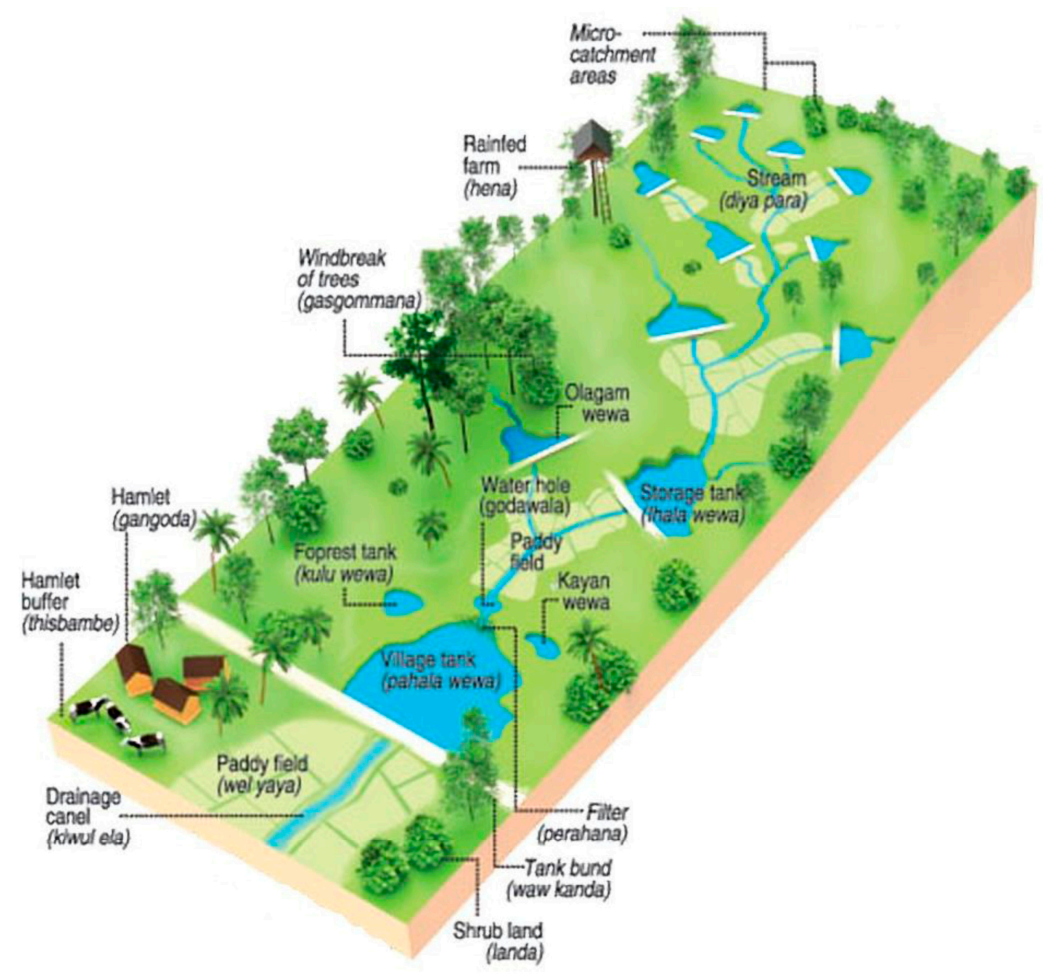

Figure 2. A drawing of a tank cascade system [31].

A key characteristic of the hydro-mentality underpinning the cascade system of water management lies in its emphasis on the role of water in connecting various discrete elements of an eco-system. This point was repeatedly stressed in our interviews with farmers of the tank cascade system:

"Water is not a solitary, discrete aspect of the environment; it is part of a greater connected whole. One must consider everything to which water is connected and related. Therefore, to look at water as something to be used for cultivation or for drinking is misguided. We use the village tank for all our needs, be it for farming, drinking, or feeding the animals. To focus only on cultivation doesn't keep with traditional principles of the interdependence of all living things".

(Field notes translated, 2018)

Frequently, the farmers who were interviewed also referred to the Theravada Buddhist doctrine of Pratītyasamutpāda, which can be translated as dependent-arising [33]. It is important to note that the doctrine of Pratityasamutpāda is very different from that of causality as it is understood in the west. Instead of referring to a direct Newtonian form of causality, the concept of Pratītyasamutpāda in Buddhism refers to conditions resulting from a plurality of causes that necessarily co-originate phenomena within and across lifetimes. As such, there is reason to support the assumption that this concept of a plurality of causes directly underpins the interconnected eco-systems approach that farmers of the tank cascade system apply to water. 
Another noteworthy observation related to the above concerns is the fact that the tank cascade system of water management has uniquely evolved in Sri Lanka under the influence of Theravada Buddhism, the dominant religion in Sri Lanka since the second century BC. Further, Buddhist monks of any given village have traditionally played a dominant role in shaping socio-cultural perspectives of that village and are often consulted on water management decisions and lead agro-based cultural festivities. Given the nexus between Buddhism, water management and agriculture, it is reasonable to assume that the hydro-mentality underlying the tank cascade system of water management has been shaped according to tenets of the Buddhist doctrine.

Assuming the above, it is important to understand how the hydro-mentality underpinning the tank cascade system is applied to the arrangement of water infrastructures and decisions regarding water use, management and governance. Firstly, the water infrastructure of the tank cascade system is distinct in that the waterways are naturalized-i.e., all elements of the water infrastructure (tanks, paddy fields, watersheds, canals, etc.) are integrated in the natural environment. There has been no deforestation or any major attempt at altering the land's topography to suit the deployment of water to a maximum possible extent. Further, paddy fields and other sites of cultivation are not permanent fixtures. Rather, villagers of a tank cascade follow a form of slash-and-burn cultivation, whereby a certain area is cleared and cultivated and then abandoned to allow trees to grow back again. In sum, the entire layout of water infrastructure demonstrates a strong commitment to the environment and a realization of the interdependence of the various elements that form an eco-system.

Second, the hydro-mentality of tank cascade systems also manifests in terms of drinking water. In the tank cascade system, the central tank, the source of all of the water for cultivation, is also the central source of drinking water. Typically, the existence of a small to moderately sized tank raises the groundwater levels in the immediate environment. Farmers capitalize on this by digging a series of wells near the tank body, which they use to extract water for drinking and washing. As such, there is no separation of the water used for cultivation and water used for drinking-this feature too is essentially a hallmark of the hydro-mentality of the interconnectedness pervading the tank cascade system. It should also be noted that since water is drawn directly from wells, it does not resemble the end-of-pipe treatment of water typically observed in a more urban environment. Bakker [34] noted that since people living in urban environments are so far removed from sources of water (for them, water is merely the end-product that they obtain at the end of a pipeline), they predominantly view water as a resource and not as part of the larger environment. This stands in stark contrast to the ways that water is perceived in communities hydraulically supported by the tank cascade. In sum, it can be argued that the unique hydro-mentality pervading tank cascade systems does not separate one use of water from another, and therefore does not separate or prioritize different forms of water above others, i.e., it does not prioritize the development of infrastructure that helps obtain the maximum level of cultivation utility from water as is done in many contemporary irrigation systems [35].

\subsection{The Hydro-Mentality Characterizing the Surface Irrigation System}

The surface irrigation system of water management, unlike the tank cascade system, is a recent addition to Sri Lankan irrigated landscapes. The modern "surface irrigation system design" has been used in Sri Lanka in designing the water infrastructure for large-scale state-sponsored agricultural extension programmes [27]. One surface irrigation system in Sri Lanka is the Mahaweli Development Project, through which water from the Mahaweli River (the longest river in Sri Lanka and the namesake of the project) is used as a stable water source year-round for cultivating paddy lands.

Water from the Mahaweli River is used to fill tanks at strategic locations. A network of canals brings water from the main canal and branches off into branch (or B-canals), distributary (or D-canals), sub-distribution (or SD-canals) and field canals. Engineers have assumed the presence of a predetermined canal slope and have applied hydraulic equations to determine the slopes and cross-sections of the canal to transport water via gravity and to cultivate to the maximum possible extent. In this design, canals are arranged across a rigid matrix-like grid of straight horizontal and 
vertical lines (see Figure 3). Landscape features such as forests in these potentially irrigable areas have been cleared to render the land topography uniform and flat. Independent farming plots and housing for the farmers were then built along canal networks. The introduction of surface irrigation systems reflects the Sri Lankan government's commitment to promoting commercial agriculture in the country. Like the case of the tank cascade system, we argue that the surface irrigation system in Thambuttegama is also shaped and informed by a particular hydro-mentality based on the premise of commercialization.

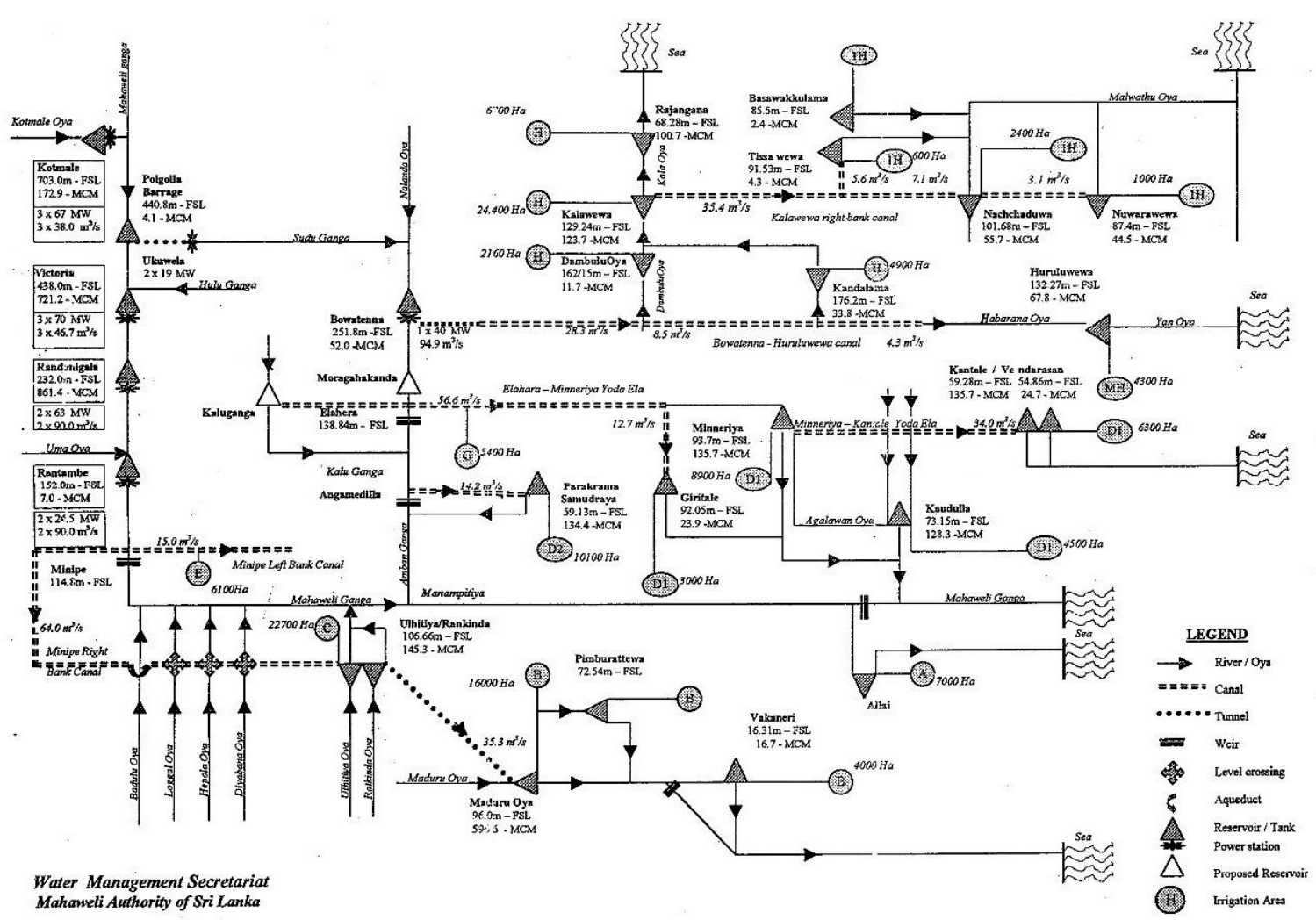

Figure 3. A cross-section of the dam, tank and canal network of the surface irrigation system created through the Mahaweli Development Project [31].

The commercial motive that underpins the surface irrigation systems of Sri Lanka can be illuminated with several examples. For one, the master plan for the surface irrigation system of Thambuttegama shows that the design features of the system used in Sri Lanka have been inspired by large-scale commercial agrarian projects and specifically by structural designs applied in the Tennessee Valley Project, USA and the Murray Darling Project, Australia. Commercial farming projects carried out in the West and in Australasia in the 20th century have focused on achieving the highest levels of water utility to farm the largest possible areas, and this philosophy is also observed in the surface irrigation systems of Thambuttegama.

Second, and related to the design features argument, it can be argued that agricultural production in surface irrigation systems is perceived as a macro-level concern by the government and by farmers. It should be observed that under the tank cascade system, each tank serves as an exclusive water source to a particular village, and thus different villages (with their own tanks) do not need to synchronize their cultivation timetables. However, as the surface irrigation system uses a common water source (water from the Mahaweli River), farmers' surface irrigation system timetables must be synchronized. This corresponds with the commercial motives described above, as the government would need to monitor, predict and calculate the agricultural output in relation to the whole system to reach the export targets related to irrigation. 
Similar to that observed in the tank cascade system, the particular hydro-mentality present in surface irrigation systems has important consequences. We find from the tank cascade system that various uses of water are not segregated or prioritized. In the surface irrigation system, on the other hand, there is a clear segregation and prioritization of the cultivation aspects of water. This segregation is reinforced by the fact that the farmers of surface irrigation systems do not perceive water at its source: the Mahaweli River. Water for them is a substance received via a network of canals. The detachment of farmers from water-related decision making (as each farmer receives a specific volume of water at a time predetermined by state representatives) further causes farmers to increasingly view water as an economic good that only has commercial value. Thus, in contrast to farmers of the tank cascade system, farmers of the surface irrigation system do not use the water that they receive through cultivation channels for other domestic purposes like drinking or washing.

This segregation and prioritization of cultivation is often accompanied by several important consequences. For instance, the water-as-an-economic-resource mindset has led the government to pay inadequate attention to ensuring a suitable drinking water supply. Further, as the primary water source is situated quite far away from farmers of surface irrigation systems, there is an insufficient level of groundwater in the area. In the words of one farmer:

"There is a massive shortage of water in this area. There is not enough of water to go around ... as a matter of fact, there is only one well of every three or four families and that too is hardly sufficient for our needs. We can't find clean water to drink, nor can we use water in the canals for fear of contracting ailments like kidney disease-it is full of pesticides. When a family accidentally stumbles on a groundwater-rich source on their land, their first move is always to bottle up the water in plastic bottles and sell it for ridiculously high prices".

(Field notes translated, 2018)

Furthermore, the surface irrigation systems of Thambuttegama, also utilizes chemical pesticides as opposed to natural pesticides in their treatment of farms, a practice which cross-contaminates the water flows from the Mahaweli River. Thus, at a practical level, the water from the irrigation canals are unusable for drinking purposes, leaving farmers with a need for alternative water sources [36].

On the other hand, the commercial motive, the focus on the use of water as a resource and the availability of a stable water source (from the Mahaweli river) throughout the year has led to a relatively higher agricultural output in the surface irrigation systems when compared to the performance of the tank cascade system. For instance, the cropping intensity (the number of crops produced annually from the same field) for surface irrigation systems watered by the Mahaweli river is nearly three times of that seen in the tank cascade system. This leads to the farmers of surface irrigation systems receiving a better income around the year, in relation to the farmers of the tank cascade system. In the words of a farmer:

"To be sure, farming here [in Thambuttegama] is more profitable in terms of the money we make. I used to cultivate in a tank cascade systems in the lowlands, where we cultivate once, or maybe twice a year. Even then, we don't really make enough money to get by, so for the rest of the year we end up working odd jobs or run small businesses. In the Mahaweli systems, on the other hand, we can earn enough to live from just farming. We can also insure our fields and buy pesticides, tractors, and other tools, all at a much cheaper rate".

(Field notes translated, 2018)

While it is not the purpose of the present work to evaluate in-depth the merits and shortcomings of either the tank cascade or the surface irrigation system, the above examples serve to further the central argument of this work: that the unique hydro-mentalities that underpin various systems of water governance, use and management have very real and political consequences that must be acknowledged and addressed. In many respects these different hydro-mentalities can be situated at opposite ends of a spectrum with respect to the ways that water is perceived (see Table 1). 
Table 1. A comparison of the hydro-mentalities and associated water infrastructure in the tank cascade system and the surface irrigation system.

\begin{tabular}{|c|c|c|c|}
\hline & & Tank Cascade System & Surface Irrigation System \\
\hline $\begin{array}{l}\text { Features of the underlying } \\
\text { hydro-mentality }\end{array}$ & $\begin{array}{l}1 . \\
2 . \\
3 .\end{array}$ & $\begin{array}{l}\text { Is underlined by a cultural } \\
\text { mindset of } \\
\text { 'interconnectedness'. } \\
\text { Views water as a substance } \\
\text { connecting different } \\
\text { elements of the eco-system. } \\
\text { Primarily micro-scale in } \\
\text { outlook. Each group of } \\
\text { farmer maintains a degree } \\
\text { of independence. }\end{array}$ & $\begin{array}{l}\text { 1. Is underlined by a mindset } \\
\text { of commercialization. } \\
\text { 2. Views water as a resource. } \\
\text { 3. Primarily macro-scale in outlook. } \\
\text { Decisions are made by the } \\
\text { systems administration. }\end{array}$ \\
\hline $\begin{array}{c}\text { Systemic infrastructural } \\
\text { differences }\end{array}$ & 1. & $\begin{array}{l}\text { The infrastructure allows for } \\
\text { multi-purpose use of water. } \\
\text { Water is used for farming, } \\
\text { personal consumption, cattle } \\
\text { farming etc. } \\
\text { The absence of a stable water } \\
\text { source leads to low levels of } \\
\text { cropping intensity and less } \\
\text { agricultural productivity. }\end{array}$ & $\begin{array}{l}\text { 1. The infrastructure creates an explicit } \\
\text { and implicit separation between water } \\
\text { for cultivation purposes. } \\
\text { 2. In certain areas, individuals are } \\
\text { explicitly instructed not to use water } \\
\text { directed to and from cultivation outlets } \\
\text { for alterative (domestic) purposes. } \\
\text { Even in areas without formal } \\
\text { prohibition, cultivation-water is often } \\
\text { contaminated with pesticides, } \\
\text { rendering it undrinkable. } \\
\text { The presence of a stable water source } \\
\text { leads to high levels of cropping } \\
\text { intensity and less } \\
\text { agricultural productivity. }\end{array}$ \\
\hline
\end{tabular}

Finally, we have noted that some farmers of the Thambuttegama surface irrigation system were formerly cultivators in the tank cascade system, since the Mahaweli project appropriated and demolished the existing tank cascades in the North Central province. Interviews with these farmers provides us with an insight as to the difficulties they encountered in adjusting to the new system:

"Farming in [Thambuttegama] is a very different experience from farming in the tank cascade system. Here, we have almost no input into the decision making processes. We get a detailed timetable from the Unit Manager [an officer employed by the Mahaweli Project] as to when and how much water we will receive each season. We are told what crops to cultivate each season. We are told what pesticides to use, and what tools are available for purchase. It's more like doing a day job, and for me it feels like giving up the initiative, you know ... but the money is better, and on average it feels like we have to do less ... ".

(Field notes translated, 2018)

Clearly, these difficulties stem from the differences in scale used in the two irrigation systems. The tank cascade system has a micro-scale decision making process that provides farmers with more initiative, when compared with the surface irrigation systems of the Mahaweli project that operates on a macro-scale. This creates a notable difference in how the activity of farming is perceived-in tank cascade systems and in surface irrigation systems. As such, it is not easy for farmers who are accustomed to a particular hydro-mentality to shift to a different paradigm. It is also significant to note that the farmers' difficulty in adjusting to a novel form of irrigation stems more from having to change their perception regarding the availability and use of water and agro-related inputs (i.e., the embedded hydro-mentality) than the technical or infrastructural challenges presented. 


\section{Discussion}

The present work sought to highlight the possibility of multiple hydro-mentalities existing with regard to water and how these different hydro-mentalities have a very real effect on the ways water use, management and governance are shaped across various socio-cultural groups. The present work identifies two different hydro-mentalities that govern the tank cascade and surface irrigation systems. Underpinning each hydro-mentality is a constellation of hydrologics, socio-cultural factors, and infrastructural arrangements. The hydro-mentality of the tank cascade system places an emphasis on water as a connecting thread between various discrete aspects of the environment, whilst the hydro-mentality of the surface irrigation system focuses on utilizing water as a resource.

Making a case for multiple hydro-mentalities as we have done above raises a number of questions. For instance, is there room for a dialogue among multiple hydro-mentalities and, if so, how might that look in practice? Typically, the literature related to this question seems to show that certain ways of thinking about water have been hegemonized over other ways of thinking, though not necessarily in terms of hydro-mentalities. Boelens [9], for example, has shown how diverse water worlds have been subjugated by certain dominant socio-natural orders that position humans and non-humans within hierarchical hydrosocial patterns. Linton [37] investigates one such dominant socio-natural order that structures a particular understanding of water-expressed in the form of a "hydrologic cycle"-and how that particular understanding (although widely endorsed and hegemonic) is increasingly at odds with the current social and hydrological experiences. Goldman [38] and Mukhtarov [39], in particular, have explored how certain water policies, water logics, hydrosocialities and hydro-mentalities have travelled across the globe via a myriad of policy networks, and how they have been historically supported by global development institutions such as the International Monitory Fund and the World Bank. The promotion of certain hydrologics is also underscored by the supply-demand equations of open-markets and capitalist economies-a fact that is demonstrated through the prevalence of mega water projects seeking to alter entire hydraulic landscapes in the hope of increasing agricultural productivity [40].

Certainly, the surface irrigation system model that is posited by the Mahaweli Development Project in Thambuttegama (and many other areas in Sri Lanka) is somewhat reflective of the mega water projects carried out in the USA, Australia and in many other parts of the developed world in terms of the conceptualization of water. As such, the surface irrigation systems posited by the Mahaweli Development Project in Thambuttegama has often been considered as "modernist" and "superior" to the indigenous tank cascade system, in terms of the agricultural output. The surface irrigation systems also closely correspond to the techno-realist water paradigms that we touched on in the introduction to this work, embodying the idea of water as a resource to be managed. On the other hand, those critical of the Mahaweli Project have often sought to romanticize the tank cascade system by referring to its eco-friendly nature, despite being relatively modest in its agrarian output. The present work is, in many ways, attempts to demonstrate that different hydro-mentalities that give rise to water infrastructural systems, each with their own relative strengths and weaknesses. Thus, it seems that a dialogue between the different hydro-mentalities would be most beneficial from a policy-oriented standpoint, but how might this be done in practice?

As these related hydro-mentalities start to assert themselves in the problem space of water governance, we need new analytical approaches that recognize how multiple hydro-mentalities should frame governance frameworks and the related forms of water management. One that can be proposed is the notion of hydrosocial multiplicity, which stresses a re-politicization and re-affirmation of all indigenous and non-hegemonic frameworks of water management [14,41]. We argue that prioritizing multiplicity over singularity means necessarily engaging in a dialogue across hydro-mentalities by broadening self-enclosed western perspectives on the matter and by engaging in a process of mutual co-learning. Mutual co-learning can be fostered through situated engagements with pluralism [42], where interactions are contextualized and concepts and practices in turn become reliant on specific circumstances for their relevance and meaning, making it possible to acknowledge the multiple 
epistemological and ontological dimensions that may exist. Further, in the specific case of Sri Lanka it would be useful to employ regional monitoring systems within tank cascade and surface irrigation systems, which involves a group of people who collect their own data for their own resource planning, management and decision making purposes. Employing distinct institutions for each system may arguably serve to retain the relative independence of each water system, while preserving the underlying hydro-mentalities and connecting across politically imposed boundaries.

\section{Conclusions}

The present work identifies the existence of various hydro-mentalities (fashioned by a collection of water management philosophies and infrastructural arrangements) in Sri Lanka and demonstrates how these hydro-mentalities underpin decisions regarding the use, management, and governance of water systems. Practically, a key insight from the introduction on the concept of hydro-mentalities is the need to open up established (and arguably hegemonic) approaches to water governance. This work has also focused on what multiple hydro-mentalities can bring to water governance by pluralizing both our understanding of what water is and our ideas of what management and governance entail.

Finally, this work suggests that researchers of water management take seriously the implications of different hydro-mentalities, as this would arguably improve the socio-political sensitivity of novel water policies. To this end, it is necessary to develop a new research agenda with a strong focus on qualitative ethnographic approaches to identify the various hydro-mentalities that underpin a variety of indigenous water systems. While some work along these lines has already been undertaken among the First Nations of British Columbia in Canada [43], additional research should be conducted on different continents to support a viable and beneficial dialogue across hydro-mentalities. It is our hope that the present work raises awareness of this aspect of water management in environmental governance realms.

Author Contributions: K.P. designed the study and co-authored the manuscript; N.Y. analyzed the data and co-authored the manuscript. All authors have read and agreed to the published version of the manuscript.

Funding: This research did not receive any specific grant from funding agencies in the public, commercial, or not-for-profit sectors.

Acknowledgments: The authors would like to acknowledge the valuable assistance provided by officers of the Mahaweli Authority of Sri Lanka in organizing the fieldwork for this study.

Conflicts of Interest: The authors declare no conflict of interest.

\section{References}

1. Blaser, M. Ontology and Indigeneity: On the Political Ontology of Heterogeneous Assemblages. Cult. Geogr. 2012, 21, 49-58. [CrossRef]

2. Blaser, M. The threat of the Yrmo: The political ontology of a sustainable hunting program. Am. Anthropol. 2009, 111, 10-20. [CrossRef]

3. Blaser, M. Ontological conflicts and the stories of peoples in spite of europe. Curr. Anthropol. 2013, 54, 547-568. [CrossRef]

4. Zeitoun, M.; Warner, J. Hydro-hegemony-A framework for analysis of trans-boundary water conflicts. Water Policy 2006, 8, 435-460. [CrossRef]

5. Warner, J.; Mirumachi, N.; Farnum, R.L.; Grandi, M.; Menga, F.; Zeitoun, M. Transboundary 'Hydro-Hegemony': 10 Years later. Wiley Interdiscip. Rev. Water 2017, 4, e1242. [CrossRef]

6. Zeitoun, M.; Allan, J.A. Applying hegemony and power theory to transboundary water analysis. Hydrol. Res. 2008, 10, 3-12. [CrossRef]

7. Al Radif, A. Integrated water resources management (IWRM): An approach to face the challenges of the next century and to avert future crises. Desalination 1999, 124, 145-153. [CrossRef]

8. Benson, D.; Gain, A.K.; Rouillard, J.J. Water governance in a comparative perspective: From IWRM to a 'Nexus' approach. Water Altern. 2015, 8, 756-773. 
9. Boelens, R. Cultural politics and the hydrosocial cycle: Water, power and identity in the andean highlands. Geoforum 2014, 57, 234-247. [CrossRef]

10. Eichelberger, L. Spoiling and sustainability: Technology, water insecurity, and visibility in Arctic Alaska. Med. Anthropol. 2014, 33, 478-496. [CrossRef]

11. Krause, F.; Strang, V. Thinking relationships through water. Soc. Nat. Resour. 2016, 29, 1-6. [CrossRef]

12. Linton, J.; Budds, J. The hydrosocial cycle: Defining and mobilizing a relational-dialectical approach to water. Geoforum 2014, 57, 170-180. [CrossRef]

13. Swyngedouw, E. The political economy and political ecology of the hydro-social cycle. J. Contemp. Water Res. Educ. 2009, 142, 56-60. [CrossRef]

14. Wilson, N.J. Indigenous water governance: Insights from the hydrosocial relations of the koyukon athabascan village of Ruby, Alaska. Geoforum 2014, 57, 1-11. [CrossRef]

15. Wilson, N.J.; Inkster, J. Respecting water: Indigenous water governance, ontologies, and the politics of kinship on the ground. Environ. Plan. E Nat. Space 2018, 1, 516-538. [CrossRef]

16. Barnes, J.; Alatout, S. Water worlds: Introduction to the special issue of social studies of science. Soc. Stud. Sci. 2012, 42, 483-488. [CrossRef]

17. Boelens, R.; Hoogesteger, J.; Swyngedouw, E.; Vos, J.; Wester, P. Hydrosocial territories: A political ecology perspective. Water Int. 2016, 41, 1-14. [CrossRef]

18. Wickramasinghe, N. Sri Lanka in the Modern Age: A History; Oxford University Press: Oxford, UK, 2015.

19. Perera, M.P. Groundwater exploration for Agro-Well development in Sri Lanka and the current status. Int. Res. J. Hum. Resour. Soc. Sci. 2017, 4, 359-373.

20. Perera, M.P.; Nianthi, R. The impact of Agro-Well development on floral diversity in tank cascades in the dry zone of Sri Lanka. Int. J. Sci. Res. (IJSR) 2016, 5, 2061-2065. [CrossRef]

21. Geekiyanage, N.; Pushpakumara, D. Ecology of ancient tank cascade systems in Island Sri Lanka. J. Mar. Isl. Cult. 2013, 2, 93-101. [CrossRef]

22. Jayasuriya, B.P.W.; Ranasinghe, D.M.S.H.K.; Maddumabandara, C.M. Socio-Cultural, ecological and managerial perspectives of a selected cascade tank system in anuradhapura district, Sri Lanka. Int. J. Multidiscip. Stud. 2017, 4, 41. [CrossRef]

23. Köpke, S.; Withanachchi, S.S.; Pathiranage, R.; Withanachchi, C.R.; Ploeger, A. Social-ecological dynamics in irrigated agriculture in dry zone Sri Lanka: A political ecology. Sustain. Water Resour. Manag. 2018, 5 , 629-637. [CrossRef]

24. Chemjong, H.; Wijesekera, N. Evaluation of Irrigation Water Issue Practice for Better Water Management at Rajangana Reservoir, Sri Lanka. In Proceedings of the UMCSAWM Water Conference on Demonstrating the Strength of Water Engineering and Management Capability Through Case Study Applications, Moratuwa, Sri Lanka, 19 January 2017; pp. 41-51.

25. Esham, M.; Garforth, C. Agricultural adaptation to climate change: Insights from a farming community in Sri Lanka. Mitig. Adapt. Strat. Glob. Chang. 2012, 18, 535-549. [CrossRef]

26. Paranage, K. The social consequences of legal principles: Investigating the origins of squatting in Sri Lanka's land settlement schemes. Eur. Sci. J. ESJ 2017, 13, 294-305. [CrossRef]

27. Paranage, K. Constructing the 'Legalities' of encroachments in dam, canal, and stream reservations in the north-central province of Sri Lanka. Dev. Stud. Res. 2018, 5, 59-68. [CrossRef]

28. Markee, N. Emic and Etic in Qualitative Research. In The Encyclopedia of Applied Linguistics; Chapelle, C.A., Ed.; John Wiley and Sons: Hoboken, NJ, USA, 2012; pp. 1-4.

29. Bandara, C.M.M. Tank Cascade Systems in Sri Lanka: Some Thoughts on Their Development Implications. In Summaries of Papers Presented at Irrigation Research Management Unit Seminar Series during 1994; Haq, K.A., Wijayaratne, C.M., Samarasekera, B.M.S., Eds.; IIMI: Colombo, Sri Lanka, 1995; pp. 1-10.

30. Brohier, R.L. Ancient Irrigation Works in Ceylon; Ministry of Mahaweli Development: Colombo, Sri Lanka, 1980.

31. Paranage, K. Understanding the relationship between water infrastructure and socio-political configurations: A case study from Sri Lanka. Water 2018, 10, 1402. [CrossRef]

32. Marambe, B.; Pushpakumara, G.; Silva, P. Biodiversity and Agrobiodiversity in Sri Lanka: Village Tank Systems. In The Biodiversity Observation Network in the Asia-Pacific Region: Toward Further Development of Monitoring; Nakano, S.I., Yahara, T., Nakashizuka, T., Eds.; Springer: Tokyo, Japan, 2012; pp. 403-430.

33. Egge, J. Religious Giving and the Invention of Karma in Theravada Buddhism; Routledge: Abingdon, UK, 2002. 
34. Bakker, K. Neoliberal Nature, Ecological Fixes, and the Pitfalls of Comparative Research. Environ. Plan. A Econ. Space 2009, 41, 1781-1787. [CrossRef]

35. Desai, P.; Himel, V. Comparative safety of various intracanal irrigation systems. J. Endod. 2009, 35, 545-549. [CrossRef]

36. Dharmaratne, R.W. Fluoride in drinking water and diet: The causative factor of chronic kidney diseases in the north central province of Sri Lanka. Environ. Health Prev. Med. 2015, 20, 237-242. [CrossRef]

37. Linton, J. Is the hydrologic cycle sustainable? A historical-geographical critique of a modern concept. Ann. Assoc. Am. Geogr. 2008, 98, 630-649. [CrossRef]

38. Goldman, M. How "Water for All!" policy became hegemonic: The power of the world bank and its transnational policy networks. Geoforum 2007, 38, 786-800. [CrossRef]

39. Mukhtarov, F. Rethinking the travel of ideas: Policy translation in the water sector. Policy Politic 2014, 42, 71-88. [CrossRef]

40. Boelens, R.; Shah, E.; Bruins, B. Contested knowledges: Large dams and mega-hydraulic development. Water 2019, 11, 416. [CrossRef]

41. Perreault, T. State restructuring and the scale politics of rural water governance in Bolivia. Environ. Plan. A Econ. Space 2005, 37, 263-284. [CrossRef]

42. Wouters, P.; Tran, T. Out of the Mainstream: Water Rights, Politics and Identity. Boelens, R., Getches D., Guevara Gil, A., Eds.; Earthscan: London, UK, 2010. ISBN: 978-1-844-07676-5. Mt. Res. Dev. 2011, 31, 270-271. [CrossRef]

43. Norman, E.S.; Bakker, K. Transgressing Scales: Water governance across the Canada-U.S. Borderland. Ann. Assoc. Am. Geogr. 2009, 99, 99-117. [CrossRef]

(C) 2020 by the authors. Licensee MDPI, Basel, Switzerland. This article is an open access article distributed under the terms and conditions of the Creative Commons Attribution (CC BY) license (http://creativecommons.org/licenses/by/4.0/). 